\title{
ANALISIS LAPORAN KEUANGAN DENGAN MENGGUNAKAN METODE HORIZONTAL PADA BANK RAKYAT INDONESIA AGRONIAGA TBK TAHUN 2016-2019
}

\author{
Radna Nurmalina \\ Prodi D3 Akuntansi, Jurusan Ekonomi dan Bisnis, Politeknik Negeri Tanah Laut \\ Jl. Ahmad Yani KM 6, Desa Panggung, Pelaihari \\ radna@politala.ac.id
}

Diterima: 05 Agustus 2020. Disetujui: 28 Desember 2020. Dipublikasikan: Desember 2020

\begin{abstract}
Abstrak
Penelitian ini menggunakan metode horizontal untuk menghitung Return On Assets (ROA) dan Return On Equity (ROE) dengan sumber data dari Bank Rakyat Indonesia Agroniaga Tbk. Analisis terhadap terhadap ROA dan ROE Bank Rakyat Indonesia Agroniaga Tbk selama periode 2016-2019. Kondisi rasio ROA Bank Rakyat Indonesia Agroniaga Tbk selama 4 tahun terakhir mengalami fluktuasi karena besarnya biaya operasional. Akan tetapi, labanya masih berada di peringkat 3 dan 4. Rasio ROE Bank Rakyat Indonesia Agroniaga Tbk pada 4 tahun terakhir juga mengalami fluktuasi. Tahun 2016 mengalami penurunan sebesar $-0,12 \%$, tahun 2017 mengalami kenaikan 1,42\% . Tahun 2018 mengalami kenaikan ROE 1,92\%. Tahun 2019 mengalami penurunan sebesar 1,29\%. Fluktuasi pehitungan ROE ini disebabkan oleh keadaan ekonomi global dan ekonomi nasional yang mempengaruhi manajeman dalam mengelola Bank rakyat Indonesia.
\end{abstract}

Kata kunci: Profitabilitas, Return On Assets, Return On Equity

\section{Abstract}

This study used a horizontal method to calculate the Return On Assets (ROA) and Return On Equity (ROE) with the data source from Bank Rakyat Indonesia Agroniaga Tbk. Analysis of ROA and ROE of Bank Rakyat Indonesia Agroniaga Tbk during the 2016-2019 period. The conditions of ROA ratio of Bank Rakyat Indonesia Agroniaga Tbk for the last four years have fluctuated from years 2016 to 2019 due to the large operational costs. But the profits are still in rank 3 and 4. The ROE ratio of Bank Rakyat Indonesia Agroniaga Tbk in the last four years has also fluctuated. In 2016 the experienced the decrease $-0.12 \%, 2017$ experienced an increase $1.42 \%$, in 2018 the increase was $1.92 \%$, in 2019 it decreased by $1.29 \%$. The state of fluctuation in ROE calculation is caused by global and national economic conditions that affect management in managing Bank Rakyat Indonesia.

Keyword: Profitabilitas, Return On Assets, Return On Equity

\section{PENDAHULUAN}

Lembaga keuangan adalah lembaga yang kegiatan utamanya menghimpun dan menyalurkan dana, serta memberikan informasi keuangan dengan tujuan mendapatkan keuntungan. PT Bank Rakyat Indonesia Agroniaga Tbk, merupakan perusahaan keuangan yang bergerak dalam bidang perbankan di Indonesia. Perusahaan tersebut didirikan oleh Dana Pensiun Perkebunan Nusantara (DEPENBUN) pada tanggal 27 September 1989 yang memperoleh izin usaha dari Menteri Keuangan Republik Indonesia pada tanggal 11 Desember 1989 dan beroperasi pada tanggal 8 Februari 1980, yang kemudian di akuisisi oleh Bank Rakyat Indonesia tahun 2011.

Artikel ini akan menganalisis laporan keuangan Bank Rakyat Indonesia (BRI) Agroniaga Tbk, dengan menggunakan Metode horizontal yaitu membandingkan laporan keuangan dalam beberapa tahun (periode), sehingga dapat diketahui perkembangan dan kecenderungannya, metode ini dapat membandingkan pos yang sama untuk tahun atau periode yang berbeda, sehingga dapat memperoleh perbandingan profitabilitas dari tahun ke tahun dengan mempertimbagkan rasio Return On Asset ( ROI) dan rasio Return On Equity (ROE). ROA 
digunakan untuk mengukur efektifitas perusahaan di dalam menghasilkan keuntungan dengan memanfaatkan aset yang dimilikinya, sedangkan ROE digunakan untuk mengukur kemampuan modal Bank dalam menghasilkan laba, informasi ini sangat diperlukan untuk calon investor dan para pemegang saham yang dapat dilihat pada kinerja keuangan keuangan bank.

\section{TINJAUAN PUSTAKA}

\subsection{Laporan Keuangan}

Menurut Hery (2014) Laporan keuangan adalah memberikan informasi tentang posisi keuangan dari suatu perusahaan selain itu juga dapat memberi informasi tenteng kondisi ekonomi, industri juga bisa memberikan gambaran tentang untung atau rugi suatu perusahaan. Menurut Rizal (2019) laporan keuangan sangat dibutuhkan oleh semua perusahaan baik perusahaan dagang, jasa maupun dalam bidang perbankan, karena dengan adanya laporan keuangan pihak perusahaan dapat mengetahui kesehatan atau kondisi keuangan perusahaan. (Kakasih, et al., 2018).

\subsection{Analisis Laporan Keuangan}

Analisis laporan keuangan adalah kegiatan berfikir untuk meenguraikan akun akun laporan keuangan menjadi unit informasi yang lebih kecil dan melihat hubungannya yang bersifat signifikan atau yang memiliki makna antara satu dengan yang lain baik antara data kuantitatif maupun non kuantitatif dengan tujuan untuk mengetahui kondisi keuangan lebih dalam yang sangat penting dalam proses menghasilkan keputusan yang tepat. (Tinambunan, n.d.). Menurut Harahap (2010) Analisis laporan keuangan adalah menguraikan pos pos laporan keuangan menjadi unit informasi yang lebih kecil dan melihat hubungannya yang bersifat signifikan atau mempunyai makna antara satu dengan yang lain baik antara data kuantitatif maupun data non kuantitatif (Trianto, 2017).

\subsection{Tujuan Laporan Keuangan}

Menurut Kasmir (2012) menyatakan secara umum laporan keuangan bertujuan untuk memberikan informasi keuangan suatu perusahaan, baik pada saat tertentu maupun pada periode tertentu. Laporan keuangan juga dapat disusun secara mendadak sesuai dengan kebutuhan perusahaan maupun secara berkala.

Menurut (Sanger, et al., 2015), tujuan laporan keuangan adalah :

1. Tujuan umum menyajikan laporan posisi keuangan, hasil usaha dan perubahan posisi keuangan secara wajar sesuai prinsip akuntansi yang diterima.

2. Memberikan informasi tentang kekayaan, kewajiban, kekayaan bersih, proyeksi laba, perubahan kekayaan dan kewajiban serta informasi yang relevan.

\subsection{Analisis Horizontal}

Menurut (Suhariyanto, 2018) Analisis Horizontal (Dinamis) adalah analisis yang dilakukan dengan cara membandingkan laporan keuangan untuk beberapa periode sehingga dapat diketahui perkembangan dan kecenderungannya. Analisis ini membandingkan pos yang sama untuk beberapa periode yang berbeda. Disebut analisis dinamis karena metode ini bergerak dari tahun ke tahun (periode).

\subsection{Return On Assets (ROA)}

Return On Assets (ROA) mengukur kemampuan perusahaan dalam menghasilkan laba bersih berdasarkan tingkat aset tertentu Hanafi,(2008:42). Semakun tinggi Return On Assets suatu perusahaan semakin, semakin besar pula tingkat keuntungan yang dicapai oleh perusahaan. Return On Assets perlu dipertimbangkan oleh investor dalam berinvestasi saham, karena Return On Assets berperan sebagai indikator efesiensi perusahaan dalam menggunakan aset untuk memperoleh laba. (Ghonio, 2017) 
Kreteria Penilaian Return On Assets (ROA)

Tabel 2.1 Kreteria Penilaian Return On Assets

\begin{tabular}{|c|c|c|}
\hline Peringkat & Keterangan & Kriteria \\
\hline 1 & Peringkat 1 & $>1,5 \%$ \\
\hline 2 & Peringkat 2 & $<1,25 \% \leq 1,5 \%$ \\
\hline 3 & Peringkat 3 & $<0,5 \% \leq 1,25 \%$ \\
\hline 4 & Peringkat 4 & $<0 \% \leq 0,5 \%$ \\
\hline 5 & Peringkat 5 & $<0 \%$ \\
\hline
\end{tabular}

Sumber: Surat Edaran Bank Indonesia

Keterangan :

Peringkat 1:Menunjukkan kualitas sangat tinggi dalam mengantisipasi kerugian Peringkat 2:Menunjukkan kualitas tinggi dalam mengantisipasi kerugian Peringkat 3:Menunjukkan kualitas cukup tinggi dalam mengantisipasi kerugian Peringkat 4:Menunjukkan kualitas rendah dalam mengantisipasi kerugian Peringkat 5:Menunjukkan kualitas sangat rendah dalam mengantisipasi kerugian.

\subsection{Return On Equity (ROE)}

Return On Equity (ROE) merupakan salah satu rasio profitabilitas yang mengukur kemampuan perusahaan dan mengelola ekuitas perusahaan. Return On Equity merupakan suatu pengukuran dari hasil yang tersedia bagi para pemilik perusahaan atas modal yang mereka investasikan di dalam perusahaan. (Putri , 2015).

Menurut Aisyah (2011) Return On Equity (ROE) menggambarkan sejauh mana kemampuan perusahaan menghasilkan laba yang bisa diperoleh pemegang saham. Return On Equity mengukur kemampuan perusahaan dalam memperoleh return bagi investasi yang dilakukan oleh investor, menunjukkan seberapa besar keuntungan yang menjadi hak pemegang saham. (Rusli \& Dasar, 2014).

\section{METODE PENELITIAN}

Data kuantitatif yang digunakan pada penelitian ini berupa perhitungan total aset laba bersih dan total modal pada perbankan Bank Rakyat Indonesia Agroniaga Tbk. Sumber data diperoleh dari laporan keuangan Bank Rakyat Indonesia Agroniaga Tbk yang terdapat di website Bursa Efek Indonesia (BEI) resmi Bank Rakyat Indonesia Agroniaga Tbk tahun 2016-2019 berupa data laporan Total Assets, Total Modal dan Laba Bersih. Data yang di analisis adalah data total aset dan total ekuitas untuk mengetahui turun naiknya laba perusahaan Bank Rakyat Indonesia Argoniaga Tbk dengan mengunakan perhitungan rasio profitabilitas ROA dan ROE . Menurut Rusli \& Dasar(2014) berikut rumus yang digunakan adalah:

rumus yang digunakan untuk mencari Return On Assets:

$$
\text { Return On Asset }(\boldsymbol{R O A})=\frac{\text { Laba Bersih }}{\text { Total Assets }} \times 100 \%
$$

rumus yang digunakan untuk mencari Return On Equity:

$$
\text { Return On Equity }(\text { ROE })=\frac{\text { Laba Bersih }}{\text { Total Ekuitas }} \times 100 \%
$$

\section{HASIL DAN PEMBAHASAN}

Return On Assets digunakan untuk mengukur efektivitas perusahaan di dalam menghasilkan keuntungan dengan memanfaatkan assets yang dimilikinya. ROA di peroleh dengan cara laba bersih di bagi dengan total assets keuntungan yang didapat dari perhitungan 
Return On Assets akan di beritahukan kepada pemilik perusahaan. Berikut rumus yang digunakan untuk mencari ROA :

$$
\text { Return On Assets }(\text { ROA })=\frac{\text { Laba Bersih }}{\text { Total Assets }} \times 100 \%
$$

Berdasarkan laporan keuangan Bank Rakyat Indonesia Agroniaga Tbk mendapatkan hasil sebagai berikut :

Perhitungan Rasio ROA Bank Rakyat Indonesia Agroniaga Tbk

Tabel 4.1 Perhitungan Rasio ROA Bank Rakyat Indonesia Agroniaga Tbk

\begin{tabular}{|l|l|l|}
\hline Tahun & Total Aset & Laba Bersih \\
\hline 2016 & $\mathrm{Rp} 11.377 .960 .721$ & $-\mathrm{Rp} 2.360 .431$ \\
\hline 2017 & $\mathrm{Rp} 16.325 .247 .007$ & $\mathrm{Rp} 40.350 .379$ \\
\hline 2018 & $\mathrm{Rp} \mathrm{23.313.671.252}$ & $\mathrm{Rp} \mathrm{142.660.203}$ \\
\hline 2019 & $\mathrm{Rp} \mathrm{27.067.922.912}$ & $\mathrm{Rp} \mathrm{86.365.196}$ \\
\hline
\end{tabular}

Sumber : Laporan Keuangan Bank Rakyat Indonesia Agroniaga Tbk

$$
\begin{aligned}
(\text { ROA) } 2016= & \frac{-2.360 .431}{11.377 .960 .721} \times 100 \% \\
= & -0,020746 \\
= & -0,02 \% \\
(\text { ROA) } 2017 & =\frac{40.350 .379}{16.325 .247 .007} \times 100 \% \\
& =0,247166 \\
& =0,25 \% \\
(\text { ROA }) 2018 & =\frac{142.660 .203}{23.313 .671 .252} \times 100 \% \\
& =0,611917 \\
& =0,61 \% \\
(\text { ROA }) 2019 & =\frac{86.365 .196}{27.067 .922 .912} \times 100 \% \\
& =0,319068 \\
& =0,32 \%
\end{aligned}
$$

Hasil Rasio ROA Bank Rakyat Indonesia Agroniaga Tbk

Tabel 4.2 Hasil Rasio Bank Rakyat Indonesia Agroniaga Tbk

\begin{tabular}{|c|c|c|}
\hline Tahun & $\begin{array}{c}\text { ROA } \\
\text { (Return On Assets) }\end{array}$ & Peringkat \\
\hline 2016 & $-0,02 \%$ & Peringkat 5 \\
\hline 2017 & $0,25 \%$ & Peringkat 4 \\
\hline 2018 & $0,61 \%$ & Peringkat 3 \\
\hline 2019 & $0,32 \%$ & Peringkat 4 \\
\cline { 1 - 2 } & &
\end{tabular}

Sumber: Bank Rakyat Indonesia Agroniaga Tbk (Data diolah)

Berdasarkan tabel 4.2 dapat dilihat persentase dari rasio Return On Assets (ROA) Bank Rakyat Indonesia Agroniaga Tbk pada tahun 2016 hingga 2019 pada tabel terdapat peringkat yang merupakan bentuk penilaian kesehatan Bank Indonesia melalui Surat Edaran Bank Indonesia dari peringkat tersebut dapat disimpulkan mengenai kondisi rentabilitas atau earning bank.

\subsubsection{Return On Equity (ROE)}

Return On Equity (ROE) merupakan rasio yang digunakan untuk mengukur laba bersih dengan modal sendiri. Rasio ini menunjukan penghasilan laba atas investasi berdasarkan nilai 
buku para pemegang saham. Semakin tinggi rasio ini semakin baik, artinya posisi pemilik perusahaan semakin kuat. Berikut rumus yang digunakan untuk mencari ROE :

$$
\text { Return On Equity (ROE) }=\frac{\text { Laba Bersih }}{\text { Total Ekuitas }} \times 100 \%
$$

Berdasarkan laporan keuangan Bank Rakyat Indonesia Argoniaga Tbk mendapatkan hasil sebagai berikut:

Perhitungan Rasio ROE Bank Rakyat Indonesia Agroniaga Tbk

Tabel 4.3 Perhitungan ROE Bank Rakyat Indonesia Agroniaga Tbk

\begin{tabular}{|c|c|rr|}
\hline Tahun & Total Ekuitas & \multicolumn{2}{|c|}{ Laba Bersih } \\
\hline 2016 & $\mathrm{Rp} 1.936 .251 .540$ & -Rp 2.360 .431 \\
\hline 2017 & $\mathrm{Rp} 3.111 .284 .877$ & $\mathrm{Rp}$ & 40.350 .379 \\
\hline 2018 & $\mathrm{Rp} 4.424 .285 .816$ & $\mathrm{Rp} 142.660 .203$ \\
\hline 2019 & $\mathrm{Rp} 4.481 .704 .219$ & $\mathrm{Rp}$ & 86.365 .196 \\
\hline
\end{tabular}

Sumber: Laporan Keuangan Bank Rakyat Indonesia Agroniaga Tbk

$$
\begin{aligned}
& (\text { ROE }) \mathbf{2 0 1 6}=\frac{103.003 .152}{1.936 .251 .540} \times 100 \% \\
& =-0,121907 \\
& =-0,12 \% \\
& (\text { ROE }) 2017=\frac{40.350 .379}{3.111 .284 .877} \times 100 \% \\
& =1,296904 \\
& =1,30 \% \\
& \text { (ROE) } 2018=\frac{142.660 .203}{4.424 .285 .816} \times 100 \% \\
& =3,224480 \\
& =3,22 \% \\
& (\text { ROE }) \mathbf{2 0 1 9}=\frac{86.365 .196}{4.481704219} \times 100 \% \\
& =1,927061 \\
& =1,93 \%
\end{aligned}
$$

Hasil Rasio ROE Bank Rakyat Indonesia Agroniaga Tbk

Tabel 4.4 Hasil Rasio ROE Bank Rakyat Indonesia Agroniaga Tbk

\begin{tabular}{|c|c|}
\hline Tahun & $\begin{array}{c}\text { Return On Equity } \\
\text { (ROE) }\end{array}$ \\
\hline 2016 & $-0,12 \%$ \\
\hline 2017 & $1,30 \%$ \\
\hline 2018 & $3,22 \%$ \\
\hline 2019 & $1,93 \%$ \\
\hline
\end{tabular}

Sumber: Bank Rakyat Indonesia Agroniaga Tbk (Data diolah)

Berdasarkan tabel 4.4 ROE dapat dilihat persentase dari hasil rasio Return On Equity (ROE) Bank Rakyat Indonesia Agroniaga Tbk pada tahun 2016 hingga 2019. 


\subsection{Analisis Hasil Rasio Profitabilitas Bank Rakyat Indonesia Agroniaga Tbk}

\subsubsection{Rasio Return On Assets (ROA)}

Rasio ROA digunakan untuk mengukur keberhasilan manejemen dalam menghasilkan laba. Semakin kecil rasio ini mengindikasikan kurangnnya kemampuan manajemen bank dalam hal mengelola aktiva atau aset untuk meningkatkan pendapatan.

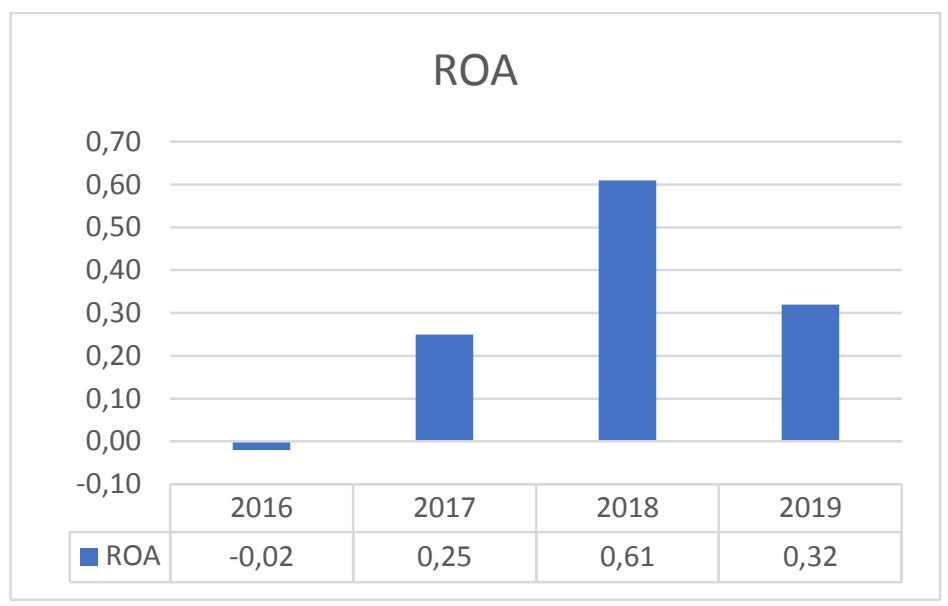

Grafik 4.1 Rasio ROA Bank Rakyat Indonesia Agroniaga Tbk

Tahun 2016 ROA Bank Rakyat Indonesia Agroniaga Tbk sebesar -0,02\% dan berada pada peringkat 5 yaitu menunjukkan kualitas ROA sangat rendah dalam mengantisipasi kerugian. Tahun 2016 ini kreditur mengalami penurunan kemampuan membayar utang, sehingga melambatnya kinerja korporasi berdampak pada kinerja perbankan. Rendahnya tingkat ROA yang dimiliki perbankan menyebabkan kecilnya tingkat keuntungan yang dihasilkan bank tersebut. Masih terbatasnya pertumbuhan kredit karena pihak perbankan sangat berhati - hati dalam menyalurkan kreditnya. Pada posisi ini perbankan menujukan kualitas sangat rendah dalam mengantisipasi kerugiannya.

Tahun 2017 ROA Bank Rakyat Indonesia Agroniaga Tbk sebesar 0,25\% dan berada di peringkat 4 , pada tahun ini pihak perbankan mampu bisa berpartisipasi dalam Program Desa Nabung sebanyak Rp. 298 Triliun, memberdayakan kredit UMKM menyalurkan kreditnya sebesar Rp. 739.3 Triliun. Kredit UMKM sebagai penyokong utama kinerja BRI sehingga mampu menghasilkan laba. Tahun 2017 ini BRI sebagai Bank yang bisa menghasilkan laba terbesar selama beberapa tahun terakhir ini.

Tahun 2018 ROA pada Bank Rakyat Indonesia Agroniaga Tbk meningkat menjadi 0,61 $\%$ berada di peringkat 3 yang berarti perusahaan mampu menurunkan beban operasional dan memaksimalkan pendapatan. Bank BRI berfokus memberdayakan UMKM dan tetap menjaga kepemimpinan untuk pangsa pasar bisnis mikro, serta melakukan trasnformasi dan terus meningkatkan kasitas dan kapabilitas pelaku UMKM.

Tahun 2019 ROA pada Bank Rakyat Indonesia Agroniaga Tbk meningkat menjadi 0,32 \% berada di peringkat 4 kualitas rendah dalam mengantisipasi kerugian. Pada tahun ini Bank BRI banyak menyalurkan kredit KPR subsidi dan kredit mikro tumbuh 13\% dan tingkat kredit bermasalah $3,08 \%$.

\subsubsection{Rasio Return On Equity (ROE)}

Diketahui bahwa rasio ROE digunakan untuk mengukur kemampuan modal bank dalam menghasilkan laba, maka semakin besar rasio ini menunjukkan kemampuan modal bank dalam menghasilkan laba semakin besar. Ini berarti semakin besar ROE maka semakin besar pula laba yang akan diterima oleh para pemegang saham. 


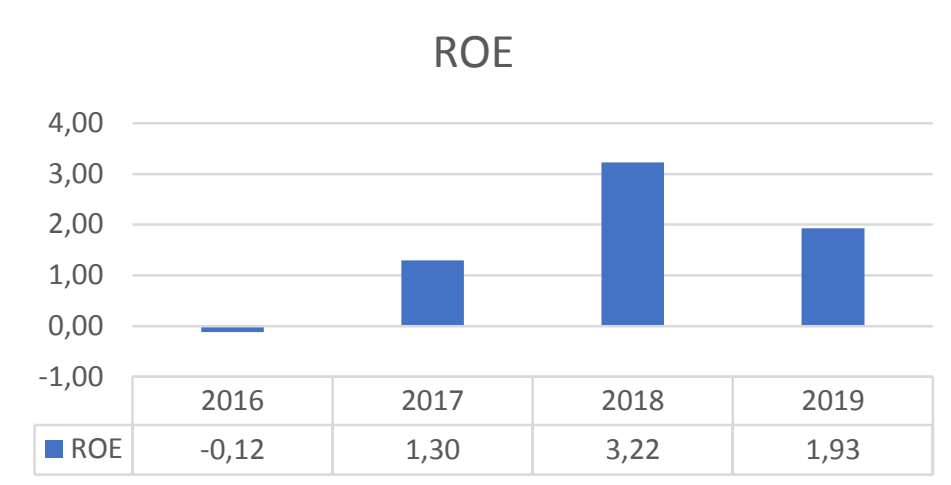

Grafik 4.2 Rasio ROE Bank Rakyat Indonesia Agroniaga Tbk

Tahun 2016 ROE Bank Rakyat Indonesia Agroniaga Tbk -0,12\%. Ini menunjukkan bahwa kemampuan modal yang di setor dalam penghasilan laba dari total modal yang dimiliki para pemegang saham sehingga laba yang akan diberikan sebesar $-0,12 \%$. Keadaan perekonomian global tahun 2016 cenderung lambat dan tidak merata yang mengakibatkan pertumbuhan ekonomi Indonesia mengalami penurunan, keadaan ini berdampak pada BRI untuk perkreditannya rendah dan juga diikuti dengan peningkatan kredit bermasalah,sehingga pertumbuhan ROE BRI sangat rendah sampai mencapai angka $-0,12 \%$.

Tahun 2017 ROE Bank Rakyat Indonesia Agroniaga Tbk menunjukkan bahwa kemampuan modal di setor sebesar $1,30 \%$. tahun ini mengalami peningkatan dari $-0,12 \%$ menjadi $1,30 \%$ peningkatannya sebesar $1,42 \%$, adanya peningkatan total modal daripada laba bersih. Pada tahun ini pertumbuhan ekonomi agak lambat, tetapi dikuartal III cukup baik dengan perbaikan ekonomi mulai meningkatnya investasi serta ekspor-impor. Surplus neraca perdagangan, kondisi stabilitas system keuangan tercermin pada rasio kecukupan modal perbankan yang cukup tinggi. Pertumbuhan konsumsi swata menguat didukung dengan nilai rupiah yang stabil dan menurunnya inflasi. Pertumbuhan investasi terus menguat didukung oleh pemulihan harga komoditas yang terus berlanjut.

Tahun 2018 kondisi perhitungan ROE pada Bank Rakyat Indonesia Agroniaga Tbk meningkat sebesar 3,22\% menunjukkan hasil yang signifikan dan mengalami peningkatan sebesar 1,92\% peningkatan laba bersih. Laba konsulidasi sebesar Rp. 14,49 triliun, kinerja BRI sangat baik untuk menghasilkan laba dengan cara menekan jumlah biaya yang dikeluarkan.

Tahun 2019 kondisi perhitungan ROE pada Bank Rakyat Indonesia Agroniaga Tbk dari $3,22 \%$ menjadi $1,93 \%$ maka terjadi penurunan ROE dari tahun sebelumnya sebesar $1,29 \%$ keadaan ini terjadi karena pertumbuhan laba BRI yang `melambat sebesar dari $11 \%$ tahun sebelumnya menjadi $8,19 \%$. Perlambatan tersebut disebabkan dua faktor yaitu kinerja anak usaha dibidang sekuritas yang membebani perseroan serta faktor kenaikan beban dana. Sebenarnya laba induk atau bank only itu sudah on the track. Sekitar 8\% laba yang dihasilkan karena terbebani dengan anak usaha yang baru diakuisisi tahun kemarin, ada banyak masalah dalam perhitungan valuasi ketika proses akuisisi. Dua anak usaha baru yang diakuisisi adalah PT.Danareksa Investasment Management dan PT. Danareksa Sekuritas.

\subsubsection{Analisis Horizontal}

Metode analisis horizontal adalah analisis dengan mengadakan perbandingan laporan keuangan menggunakan perhitungan rasio profitabilitas ROA dan ROE untuk membandingkan dari tahun 2016 sampai dengan 2019.

Rasio profitabilitas ROA tahun 2016 sebesar $-0.02 \%$ ini sangat rendah dalam mengantisipasi kerugian karena, semakin rendah ROA pada bank maka semakin kecil tingkat keuntungannya. Tahun 2017 rasio profitabilitas ROA sebesar 0,25\% manajemen bank mampu menghasilkan laba laba $0,25 \%$ dari biaya operasional dan pendapatan operasional. Pendapatan laba tahun ini meningkat karena besarnya biaya operasional, jika pendapatan lebih besar dari 
biaya operasional maka perusahaan akan mendapatkan keuntungan yang lebih besar sedangkan pada tahun 2017 keuntungannya meningkat sangat besar 0,27\% dari tahun 2016. Tahun 2018 Bank Rakyat Indonesia Agroniaga Tbk mengalami kenaikan sebesar 0,61\% dari 0,25\% menjadi 0,36\% kemampuan manajemen bank dalam menghasilkan laba tahun 2018 ini meningkat yang mana untuk mengantisipasi kerugian dalam pendapatan operasional. Tahun 2019 mengalami penurunan menjadi $0,32 \%$ kemampuan bank dalam menghasilkan laba terjadi penurunan dari $0,61 \%$ menjadi $0,32 \%$ penurunananya sebesar $0,29 \%$.

Rasio profitabilitas ROE tahun 2016 sebesar $0,12 \%$ ini menunjukkan kemampuan modal yang disetor dalam menghasilkan laba dari total modal yang dimiliki. Tahun 2017 rasio profitabilitas ROE menunjukkan bahwa kemampuan modal di setor sebesar $1,30 \%$. tahun ini mengalami kenaikan dari $0,12 \%$ menjadi $1,30 \%$ kenaikannya sebesar $1,42 \%$ karena peningkatan laba bersih daripada total modal. Tahun 2018 Bank Rakyat Indonesia Agroniaga Tbk mengalami peningkatan laba $3,22 \%$, dari $1.30 \%$ menjadi sebesar $3,22 \%$, kenaikan sebesar $1.92 \%$. Tahun 2019 rasio profitabilitas menunjukan kemampuan modal disetor sebesar 1,93\% tahun ini mengalami penurunan dari 3,22\% menjadi $1,93 \%$ jadi terjadi penurunan laba sebesar $1,29 \%$, tetapi keadaan seperti ini masih menguntungkan bagi pemilik saham.

\section{KESIMPULAN}

1. Hasil perhitungan terhadap Return On Assets (ROA) dan Return On Equity (ROE) Bank Rakyat Indonesia Agroniaga Tbk untuk perhitungan ROA tahun 2016 sebesar -0,02\% tahun 2017 sebesar 0,25\%, tahun 2018 sebesar 0,61\%, tahun 2019 sebesar 0,32\%. Perhitungan ROE tahun 2016 sebesar $-0,02 \%$, tahun 2017 sebesar 1,3\%, tahun 2018 sebesar 3,22\% dan tahun 2019 sebesar 1,93\%.

2. Analisis terhadap terhadap Return On Assets (ROA) dan Return On Equity (ROE) Bank Rakyat Indonesia Agroniaga Tbk selama periode 2016-2019 maka di dapat kondisi rasio Return On Assets (ROA) Bank Rakyat Indonesia Agroniaga Tbk selama 4 tahun terakhir mengalami fluktuasi dari tahun 2016 sampai tahun 2019 karena besarnya biaya operasional, tetapi labanya masih berada di peringkat 3 dan 4. Perlunya peningkatan kemampuan manajemen dalam mengelola aset untuk menghasilkan laba sehingga kondisi profitabilitas bank menjadi lebih baik lagi dan dapat mengantisipasi resiko serta bisa menambah modal. Sedangkan rasio Return On Equity (ROE) Bank Rakyat Indonesia Agroniaga Tbk pada 4 tahun terakhir mengalami fluktuasi dari Tahun 2016 sebesar -0,12\%, Tahun 2017 mengalami kenaikan sebesar 1,42\%. Tahun 2018 mengalami kenaikan sebesar 1,92\% Tahun 2019 mengalami penurunan sebesar 1,29\% menjadi 1,93\%. Keadaan fluktuasi pehitungan ROE ini disebabkan oleh keadaan ekonomi global dan ekonomi nasional yang mempengaruhi manajeman dalam mengelola Bank rakyat Indonesia.

\section{DAFTAR PUSTAKA}

Azmy, A., 2018. Analisis Pengaruh Rasio Kinerja Keuangan Terhadap Profitabilitas Bank Pembiayaan Rakyat Syariah Indonesia. Akuntansi, Volume Vol 22, p. 199.

Ghonio, M. G., 2017. PENGARUH RETURN ON ASSET (ROA) DAN RETURN ON EQUITY (ROE) TERHADAP HARGA SAHAM PADA PERUSAHAAN MANUFAKTUR YANG TERDAFTAR DI ASEAN PERIODE 2013-2015. Jurnal Profita, p. 5.

https://www.idx.co.id/perusahaan-tercatat/laporan-keuangan-dan-tahunan/ di akses pada tanggal 10 Februari 2020, pukul 2:30 WITA

Ihsanti, E., 2014. Pengaruh Kompotensi Sumber Daya Manusia dan Penerapan Sistem Akuntansi Keuangan Daerah Terhadap Kualitas Keuangan Daerah. p. 5.

Ikatan Akuntansi Indonesia (IAI), 2004, Standar Akuntansi Keuangan, Edisi Ketiga, Salemba Empat. Jakarta

Ikhwal , N., 2016. Analisis ROA dan ROE Terhadap Profitabilitas Bank Di Bursa Efek Indonesia. Lembaga Keuangan dan Perbankan, Volume Vol 1, p. 212. 
Kakasih, G. G., Kodong, T. I. \& Mawikere, L. M., 2018. Iptek Laporan Arus Kas Sebagai Pengukur Penilaian Kinerja Keuangan Pada PT. Bank Sulutgo. Jurnal Iptek Akuntansi Bagi Masyarakat, 02(02), p. 99.

Maith, H. A., 2013. Analisis Laporan Keuangan Dalam Mengukur Kinerja Keuangan Pada PT. Hanjaya Mandala Sampoerna Tbk.. Jurnal Emba, Volume Vol 01, p. 621.

Pongoh, M., 2013. Analisis Laporan Keuangan Untuk Menilai Kinerja Keuangan PT BUMI RESOURCES TBK.. Jurnal Emba, Volume Vol 01, p. Hal 671.

Putri , L. P., 2015. Pengaruh Profitabilitas Terhadap Harga Saham Pada Perusahaan Pertambangan Batubara di Indonesia. Jurnal Ilmiah Manajemen dan Bisnis, Volume Vol 16, p. 52.

Rusli, A. \& Dasar, T., 2014. Pengaruh Rasio Keuangan Terhadap Harga Saham Pada Perusahaan BUMN Perbankan Yang Terdaftar Di Bursa Efek Indonesia. Jurnal Akuntansi, Volume Vol 01. No.02, p. 11.

S., 2018. Analisis Laporan Keuangan Dengan Menggunakan Metode Horizontal pada PT. Bank Muamalat Indonesia Tbk Periode 2012-2016. Analisis Laporan Keuangan, Volume 2, p. 16.

Sanger, H., Tinangon , J. \& Sabijono, H., 2015. Analisis Informasi Laporan Arus Kas Sebagai Alat Ukur Efektivitas Kinerja Keuangan Pada PT. Gudang Garam TBK. Sebagai Salah Satu Perusahaan Industri Rokok Yang Terdaftar Di Bursa Efek Indonesia. Berkala Ilmiah Efisiensi, 15(05), p. 864.

Sianipar, L. U. S., 2016. Analisis Laporan Arus Kas Untuk Menilai Kinerja Keuangan Pada PT Indofood Sukses Makmur, Tbk Yang Terdaftar Di Bursa Efek Indonesia. Sultanist, 05(02), p. 84.

Tinambunan, A. P., n.d. Analisis Vertikal dan Horizontal Terhadap Laporan Keuangan PT Perkebunan Nusantara III (Persero) Medan. Manajemen dan Bisnis, Volume 17, p. 3.

Trianto, A., 2017. ANALISIS LAPORAN KEUANGAN SEBAGAI ALAT UNTUK MENILAI KINERJA KEUANGAN PERUSAHAAN PADA PT. BUKIT ASAM (PERSERO) TBK TANJUNG ENIM. JURNAL ILMIAH EKONOM, Volume Vol 8, p. 1.

Yuliarinda, A. S., 2015. Aplikasi Analisis Laporan Arus Kas Dengan Metode Vertikal dan Horizontal pada CV Ilham Tailor Yogyakarta. e-Proceeding of Applied Science, Volume 1, p. 43.

\section{Biodata Penulis}

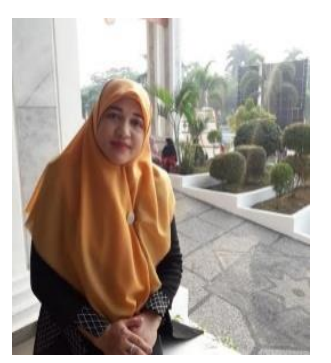

Radna Nurmalina, lahir pada tanggal 31 Mei 1970, Kota Rantau Kabupaten Tapin, Kalimantan Selatan. Penulis pada Mei 1994 menyelesaikan program Strata-1 Akuntansi di Sekolah Tinggi Malangkucecwara di Kabupaten Malang - Jawa Timur. Dan Pada Tahun 1998 penulis menyelesaikan program Starata-2 (IESP) Ilmu Ekonomi Studi Pembangunan di Universitas Negeri Syiah Kuala (UNSYIAH) di Banda Aceh Darussalam. Penulis bergabung menjadi Dosen Di Jurusan Akuntansi di Sekolah Tinggi Ilmu Ekonomi Indonesia (STIEI) Banjarmasin Di Kayu Tangi, sejak Desember 1994-2010. Pada tahun 2010 Pindah mengajar ke Politeknik Negeri Tanah Laut, karena pindah kerja mengikuti Suami, yang saat itu di fasilitasi oleh Kopertis 11 untuk pindah home base mengajarnya. Pada tahun 2010 bergabung menjadi dosen pada Program Studi D-III Teknik Informatika dan menjabat sebagai Kaprodi DIII Teknik Informatika dari tahun 2011 sampai dengan tahun 2013. Pada tahun 2017 menjadi dosen Program D-III akuntansi sampai sekarang. Penulis aktif mengajar, mengadakan penelitian dan pengabdian kepada masyarakat. Penulis dapat dihubungi melalui surel radna@politala.ac.id. 